\begin{tabular}{|c|c|c|}
\hline $\begin{array}{l}\text { ÇÜTAD } \\
\text { Çukurova Üniversitesi } \\
\text { Türkoloji Araștırmaları Dergisi }\end{array}$ & & $\begin{array}{l}\text { Cilt 6, Sayı } 2 \\
\text { Aralık } 2021\end{array}$ \\
\hline $\begin{array}{l}\text { ISSN: } 2587-1900 \\
\text { E-ISSN: } 2548-0979\end{array}$ & $\begin{array}{l}\text { Geliş Tarihi: } \\
\text { Kabul Tarihi: }\end{array}$ & $\begin{array}{l}15.04 .2021 \\
19.09 .2021\end{array}$ \\
\hline \multicolumn{3}{|c|}{$\begin{array}{l}\text { Makale Künyesi (Araştırma): Herkmen, D. (2021). Atış- ve aytış- } \\
\text { sözcüklerinin art ve eş zamanlı değerlendirmesi. Çukurova Üniversitesi } \\
\text { Türkoloji Araştırmaları Dergisi, 6(2), 649-661. }\end{array}$} \\
\hline \multicolumn{3}{|c|}{ https://doi.org/10.32321/cutad.916609 } \\
\hline
\end{tabular}

\title{
ATIŞ- VE AYTIŞ- SÖZCÜKLERININN ART VE EŞ ZAMANLI DEĞERLENDİRMESİ
}

Dilek HERKMEN ${ }^{1}$

\section{ÖZET}

Türkiye Türkçesi genel sözlüklerinde atış- ve aytış- madde başlarında "tartışmak" karşılığının ortak olduğu görülür. TDK Türkçe Sözlük ve Kubbealtı Lügati'nde atış- "tartışmak" anlamıyla yer alır. Aytış- maddesi için TDK Türkçe Sözlük ve Kubbealtı Lügati ortak olarak "halk şairleri belli bir ayak çerçevesinde karşılıklı atışmak" anlamını verirler. Fakat TDK Türkçe Sözlük aytış- maddesine "tartışmak; münakaşa etmek" anlamını da ekler. Bu maddeyi Kubbealtı atış-, TDK Türkçe Sözlük aytış- şekliyle alır. Bu değerlendirmeden ayt- fiili ile at- fiilinin türevlerinin anlamlarının karıştığı dikkati çeker. Atış- ve aytış- eylemleri art zamanlı olarak değerlendirildiğinde atış- eyleminin Divânü Lügati’t-Türk'te "herhangi bir şeyi atmak; atmakta yarışmak" anlamıyla yer aldığı, zamanla anlam alanını genişleterek "söz atmak, suç atmak" kullanımları ile varlığını sürdürdüğü görülür. Divânü Lügati’t-Türk’te aytış- eylemi "barışmak; birbirlerine sormak" anlamlarıyla sözlükte madde başı olarak yer alır. Sonrasında "hâl, hatır sormak; birbirlerine sormak; kendi aralarında konuşmak; söyleşmek" anlamlarıyla eserlerde yer alır. Bu eylemin Anadolu sahasında kullanım alanı dardır. Öndamaksıllaşmış şekli ile daha çok kullanılan aytışeyleminin Osmanlı Türkçesi dönemi eserlerinde tespit edilememesi, atışma sözcüğünün at- kökünden geldiğini düşündürmektedir. Bununla birlikte aytışma sözcüğünün güncelleme yoluyla atışma şeklini alması da kuvvetli bir ihtimaldir.

Anahtar kelimeler: Atışmak, aytışmak, atışma, anlam değişmesi, etimoloji, güncelleme.

\footnotetext{
${ }^{1}$ Mimar Sinan Güzel Sanatlar Üniversitesi, Fen Edebiyat Fakültesi, Türk Dili ve Edebiyatı Bölümü, Dr. Öğretim Üyesi. dilek.herkmen@msgsu.edu.tr, dilekherkmen@yahoo.com https://orcid.org/0000-0002-3060-3756
} 


\title{
DIACHRONIC AND SYNCRONIC ASSESMENT OF ATIŞ- AND AYTIŞ- WORDS
}

\begin{abstract}
In the general dictionaries of Turkey Turkish, it is seen that the equivalent of "arguing" is given for atış- and aytış- clauses. Atış- takes place in the TDK Turkish Dictionary and Kubbealtı Lügati with the meaning of "discuss". For the aytı̧- item, TDK Turkish Dictionary and Kubbealtı Lügati jointly mean minstrel to contest within a certain rhyme (melody). However, in the TDK Turkish Dictionary, aytış- item also means "to argue, to quarrel". This item is in the form of atı̧- in Kubbealtı and is in the form of aytış- in TDK Turkish Dictionary. It draws attention that the meanings of the derivatives of the verb aytand the verb at- are confused. When the verbs atı̧s- and aytış- are evaluated as diachronic, it is seen that the verb of atış- takes place in the Divânü Lügati’t-Türk meaning "throwing anything, competing in throwing" and continues its existence with the use of "to ironie, to calumniate" by expanding its meaning over time. In Divânü Lügati'tTürk aytış- verb, takes place as an item with the meanings of "to make peace, to ask each other". Afterwards, it takes place in the works with the meaning of "ask after someone, asking each other, talking among themselves, talking”. The usage of this verb in the Anatolian Turkish field is narrow. Since the word aytıs-, which is more commonly used in its palatalized form, could not be identified in Ottoman Turkish period works, suggest that the word atışma comes from the root at. However, there is a strong possibility that the word aytı̧sma will take the form of atışma through updating.
\end{abstract}

Keywords: Atışmak, aytışmak, atışma, change of meaning, etymology, updating.

\section{Gíriş}

Türk Dil Kurumuna ait Türkçe Sözlük’te atış- “tartışmak; kendisine dargın olan bir kimseye barışıkmış gibi söz söylemek; çocuk oyunlarında ebeyi veya takımda olanları belirlemek için karşılıklı olarak adım atmak" anlamları ile verilir. Sözlükte aytışmaddesi için ise "atışmak, tartışmak, münakaşa etmek; halk şairleri belli bir ayak çerçevesinde karşılıklı atışmak" anlamları kayıtlıdır. "Tartışmak" her iki madde için ortak anlamdır. Bununla birlikte Türkçe Sözlük'te atışma kelimesi “atışmak işi; saz şairleri belli bir ayak üzerine karşılıklı deyiş söyleme" şeklinde açıklanır. Anlam ilgisi atışma sözcügünün aytış- eyleminden türediğini işaret etmektedir. Çünkü "saz şairlerinin karşılıklı atışması" aytış- maddesinin açıklamasında yer almaktadır. Ayrıca Türkçe Sözlük’te aytış- ve aytışma birer madde olarak yer aldıkları hâlde her iki sözcüğe ait örnek olmadığı dikkati çeker. aytış- sözcüğü Türk Dil Kurumunun Türkçe Sözlük'ünde 1945 baskısından beri yer alır. 1945 baskısında 
yer alan "karşılıklı olarak, birkaç kişi, bir meselenin lehinde ve aleyhinde fikir ileri sürmek, münakaşa etmek" anlamına 1959'da "(ozanlar) belli bir ayak üzerine karşılıklı deyiş söylemek" anlamı eklenmiş; 1983-1998 arasında bu anlam sözlükten çıkarılmıştır. Atışmaddesi 1945 baskısında "1. birbirine atmak 2. ağız kavgası etmek 3. bir kimse dargın olduğu kimseye barışıkmış gibi söz söylemek" anlamları ile verilir. 1959 baskısında "birbirine atmak" anlamı sözlükten çıkarılır. 1969'da "(ozanlar) belli bir ayak üzerine karşılıklı deyiş söylemek" anlamı eklenir; 2005 baskısına dek bu şekilde devam eder. 2011 baskısında "çocuk oyunlarında ebeyi veya takımda olanları belirlemek için karşılıklı olarak adım atmak" anlamı eklenmiş; "saz şairlerinin atışması" çıkarılmıştır. 1969'dan itibaren aralıklı olarak "saz şairlerinin atışması" anlamının her iki maddenin açıklamasında yer alması bu sözcüklerin anlamlarının karıştığını düşündürmektedir.

Aytış- ve atış- eylemleri Kubbealtı Lügati'nde de atış- < at-l-ş"ağız kavgası yapmak, tartışmak, münâkaşa etmek"; atış- < ayt-l-şE.T. aytt- "demek, söylemek" karşılıklı söz söylemek; (saz şâirleri tarafından) aynı ayak (kāfiye) üzerine karşılıklı şiir söylemek" şeklinde iki ayrı madde hâlinde yer alır. Kubbealtı Lügati iki eylemin ayrı köklerden geldiğini belirtmekle birlikte madde başı olarak aytışşeklini almaz. Aytış- eylemin /y/ sesinin erimiş şekli olan atışformuna madde başı olarak yer verir. Ayrıca burada atışma sözü de atışma "ağız kavgası, tartışma" ve atışma "saz şâirlerinin aynı ayak (kāfiye) ile karşılıklı şiir söyleyerek yaptıkları tartışma, şiir yarışması" olarak iki ayrı maddedir.

Genel olarak bakıldığında atış- eyleminin "karşılıklı atmak" anlamına artık her iki sözlükte de yer verilmediği; "tartışmak" karşılığının ise ortak olduğu görülür. TDK Türkçe Sözlük’te Kubbealtı Lügati'nden farklı olarak "çocuk oyunlarında ebeyi veya takımda olanları belirlemek için karşılıklı olarak adım atmak" karşılığı yer alır. Aytış- maddesi için TDK Türkçe Sözlük ve Kubbealtı Lügati ortak olarak "halk şairleri belli bir ayak çerçevesinde karşılıklı atışmak" anlamını verirler; fakat "atışmak, tartışmak, münakaşa etmek" anlamı Kubbealtı Lügati'nde yer almaz. TDK Türkçe Sözlük'te de "karşılıklı söz söylemek" anlamı yoktur. Bu maddeyi Kubbealtı atış- şekliyle verirken TDK Türkçe Sözlük aytış- şekliyle alır. Bu değerlendirmelerde atış- ve aytış- madde başlarının anlamlarındaki farklar açıkça görülmektedir.

Atış- ve aytış- eylemlerinin kökenlerinin ve anlam alanlarının belirlenmesi için art zamanlı inceleme yapılmalıdır. Bu çalışma, kelimelerin tespit edilen ilk anlamlarının ve kazandıkları diğer 
anlamların belirlenmesine ve sözlük maddelerinin anlamlarının tanımlanmasına katkı sağlayacaktır.

\section{ATIŞ- VE AYTIŞ- SÖZCÜKLERININN ART ZAMANLI DEĞERLENDİRMESİ}

Atış- fiili -( $(l)$ ş işteşlik eki ile türemiştir. Tietze "atış- "ağız kavgası etmek" at- fiilinin müşareket hali" açıklaması ile verir (Tietze, 2002, s. 223). Clauson at- eylemi ile benzer anlam aralığında olduğunu belirtir (Clauson, 1972, s. 72). Stachowski atış- I "birbirine atmak veya ateş etmek"; atış II "münakaşa etmek, tartışmak" şeklinde iki ayrı madde olarak alır. Ayrıca atış- II fiilinin atış- I eyleminden anlamsal gelişim ile yoluyla ya da aytış- fiilinin fonetik değişimi ile meydana gelme ihtimalinden söz eder ve atış- I eyleminden gelişmiş olmasının mümkün olduğunu dile getirir (Stachowski, 2019, s. 67). Wilkens, Eski Uygur Türkçesinde aytış- eylemine "birbirine sormak; tartışmak; birbirine danışarak davranmak, anlaşmak, uzlaşmak, danışmak; selamlaşmak” anlamlarını verir (Wilkens, 2021, s. 90). Burada atış- eylemi yer almaz. Sözcük ilk kez 1072'de Divânü Lugati 't-Türk'te atış- "atmakta yarışmak, herhangi bir şeyi atmak için de böyle denir" ve atış "atış", atışgan "atmakta yarışmayı âdet

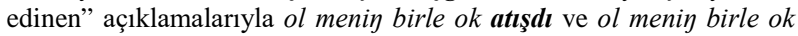
atışgan ol cümlelerinde yer alır (Ercilasun ve Akkoyunlu 2016, s. 29, 80, 92). Aytış- < ay-(l)t-(l)ş- sözcüğü Divânü Lugati't-Türk'te ayrıca olar için aytıştılar "Onlar aralarında barıştılar." (Ercilasun ve Akkoyunlu, 2016, s. 36) cümlesinde "barışmak" anlamıyla yer alır. Ayrıca Divânü Lugati't-Türk'te aytış "hâl hatır soruşma" (Ercilasun ve Akkoyunlu, 2016, s. 55) sözcügüü de mevcuttur. Clauson aytış < ayıt- "konuşma, açıklama" açıklaması ile verir (Clauson, 1972, s. 268). Karahanlı Türkçesi Satırarası Kuran Tercümesi'nde (TIEM 73) emeri üze aytışgaylar ifadesinde yer aldığ 1 görülür. Burada aytış"birbirlerine sormak, soruşturmak, birbirlerinin hâl ve hatırlarını sormak, birbirlerinden Allah adını vererek dilemek" anlamları ile yer alır (Ünlü, 2004, s. 146, 348). Karahanlı Türkçesi Satırarası Kuran Tercümesi'nde (TİEM 73) atış- eylemi ançada öldürdü̈üzler bir tenni atıştınızlar anı̀ içinde (Kök, 2004, s. 8, 280) cümlesinde tespit edilir. Bakara suresindeki 7. ayetin anlamına göre "O zaman, bir kimseyi öldürmüştünüz, (suçu) birbirinize atmıştınız” şeklinde Türkiye Türkçesine aktarılabileceği anlaşılmaktadır. Buna göre atış- "birbirine suçu yüklemek; suçu birbirine atmak" anlamını karşılamaktadır. 12. yüzyıl Harezm Türkçesi eserlerinden Mukaddimetü'l-Edeb'te ok atıştl anıy birle "onunla ok atıştı"; biri birine köz kaş atışdılar "birbirine kaş göz işareti yaptılar"; atışstılar taş birle "birbirlerine taş attılar" örneklerinde atış- "(ok, taş) atışmak"; kaş köz atış- "karşılıklı kaş göz işareti yapmak" anlamları tespit edilir (Yüce, 1988, s. 57, 72, 73). 12.- 
13. yüzyıllara ait olan Orta Asya Kur'an Tefsiri'nde bardılar takı anlar oturışdılar ya 'n̄̄ bardılar asdä söz ayduşdılar örneğinde eylem ayduş- < aytış- şeklinde sedalı ve yuvarlak biçimiyle karşımıza çıkar. Burada ayduş- "kendi aralarında konuşmak" anlamındadır (Usta ve Amanoğlu, 2002, s. 64).

14. yüzy1l Harezm Türkçesi eserlerinden Nehcü'l- Ferâdis'te kişi birle aytışursay (Eckmann, 1995, s. 38, 130) örneğinde aytış"konuşmak"; Kutb 'un Hüsrev ü Şirini'nde kamug aytıştılar bir biringe rāzın (Yıldız, 2018, s. 37, 85) kullanımında aytış- "karşılıklı söylemek"; aynı yüzyılda Sibicabi’nin Gülistan Tercümesi'nde hatun

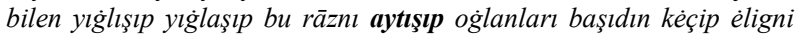
tutup cümlesinde aytış- "söyleşmek, konuşmak" olarak benzer anlam çerçevesinde yer alır (Ergene, 2017, s. 285). 15. yüzyılda Ali Şir Nevāyi'nin Nevādirü 'ş-Şebāb'inda da kim zemān āsībidin bir birge aytışsak g gamı örneğinde "karşılıklı söylemek" anlamı vardır (Karaörs, 2006, s. 600).

11. yüzyıldan 15. yüzyıla değin Doğu Türkçesi eserlerinde atışeyleminin "karşılıklı ok atmak" anlamının yanı sıra "suçu birbirine atmak" ve "kaş göz atmak" yani "karşılıklı olarak kaş göz hareketleri ile işaretleşmek" anlamlarında kullanıldığı görülür. Buradan kelimenin anlam alanının genişlediği anlaşılmaktadır. Aynı dönemde aytış- eyleminin "barışmak; hâl, hatır sormak; birbirlerine sormak; kendi aralarında konuşmak; söyleşmek" anlamlarıyla yer aldığı tespit edilir. Aytış- eylemi ilk olarak Divânü Lugati't-Türk'te görülmekle birlike; ay- Eski Türkçede "demek, söylemek, açıklamak; talimat vermek, buyurmak; yol göstermek, öğütlemek vb.”, ayt- "söylemek, demek; ad vermek" (Şirin, 2016, s. 721) anlamları ile yer alır. Buna göre aytış- eyleminin de "barışmak, hâl hatır sormak" anlamları dikkate alındığında anlam alanının genişlemiş olduğu anlaşılır.

Anadolu sahasına bakıldığında, 13. yüzyıla ait Ali'nin Klssa-i Yusuf adlı eserinde ayduş- şeklinde kalın sıradan okunduğu belirtilen sözcük "karşılıklı söyleşmek" anlamıyla kayıtlıdır (Cin, 2004, s. 528). 14. yüzyılda Şeyhoğlu Mustafa'nın Hurşid-nâme eserinde meşel kaldı henüz eydişür àdem cümlesinde eydiş- "söyleşmek, konuşmak" (Ayan, 1979, s. 278); 16. yüzy1l Vâhidî’nin Hâce-i Cihân Netîce-i Cân adlı eserinde de ādemīlerile buluşalum ve bilişelüm ve görüşselüm ve girişelüm anlaruy harekātın görüp kelimāt eydişelüm örneğinde de eydiş "söyleşmek" anlamıyla kayıtlıdır (Karabey, 2015, s. 113). Eserin aynı yüzyıla ait olan diğer iki nüshasında idişelüm şeklinde yer aldığı belirtilir. 15. - 16. yüzyıllarda yazıldığı düşünülen Dede Korkut'ta (15. 16. yüzy1llar) ag yeleklü ötkün ohlar atışayduk cümlesinde atış- "okla atışmak", ok atışın göreyim örneğinde atış "(okla) atış atma" 
anlamlarıyla geçer (Özçelik, 2016, s. 51, 505). Ayrıca bir birine söz atışdılar örneğinde söz atış- "ağız dalaşı yapmak" birleşik eyleminin kullanımı yer alır (Özçelik, 2016, s. 415). Burada aydış- / eydişkullanımları yer almaz. Tarama Sözlüğ̈̈'nde 16. yüzyıla ait olan Babusü'l-Vâsıt'ta eydiş- "söyleşmek, konuşmak" anlamıyla tanıklandığı belirtilir (Tarama Sözlüğü III, 1996, s. 1578). Aytışeyleminin Anadolu sahasında öndamaksıllaşma ile ince sıraya geçtiği ve ayrıca kalın sıradan ve yuvarlak şekillerinin de kullanıldığı görülür. Art damaksıl şekil olan aydış- örneği karışık dilli eserlerden sayılan Kıssa-i Yusuf'ta yer alır. Anadolu sahasında ey- ya da ay- eylemi kullanılmazken eyt- ve eyit- türemiş şekillerinin ayt- şeklinden sayıca fazla olduğu görülür. Eylemin eydiş- / aydış- türevinin kullanımının sık olmadığı anlaşılmaktadır. Anadolu sahasında eylemin ön damaksıl şekilleri tercih edilmiş, Osmanlı Türkçesi döneminde kullanım alanı daralmıştır.

Eski Anadolu Türkçesinde de atış- eylemi suç atış- yapısındaki gibi söz atış- kullanımıyla dikkati çeker. Atış- "birbirine atmak" anlamıyla kayıtlıdır (Tarama Sözlüğü, s. 275). 1545’te tamamlanan Ahteri-yi Kebir'de irtima maddesi "zehab gibi ok atışmak” ve "halk ok atıştı"; intizâl "ok atışmak"; terâcim "okla atışmak"; terâmî "oklaşmak ve atışmak"; tekârug "kura atışmak" açıklamaları ile verilir (Kırkkılıç ve Sancak, 2017, s. 51, 105, 175, 176, 201). 16. yüzyıla ait Lugat-ı Nimetullah'ta serengīden maddesi "güvlemek ve gin eylemek veya çavlaşmaḳ ya’ni söz atışmak"; sirengīden "yār çavlaşmak ya'nī söz atışmaḳ" şeklinde açıklanır (İnce, 2015, s. 301). Müntahabât-ı Lügât-ı Osmâniyye'de (19. yüzyıl) irtimâ maddesi "birbirine atışmak", mukaraat maddesi "nesne taksiminde kura atışmak ve kavgada birbiriyle vuruşmak" şeklinde açıklanır (Toparlı vd., 2016, s. 183, 298). Kamus-ı Türkî"de atışmak "vuruşmak, taş ve silâhla birbirine vurmak; birbirine söverek kavga etmek" şeklinde açıklanır (Şemseddin Sami, 1900, s. 21). Kamus-ı Türkî̀ de aytış- ve atışma yer almaz.

Her iki sözcügün tarihî seyrinden atış- eyleminin "tartışmak" anlamıyla Eski Anadolu Türkçesi döneminde ortaya çıktığ 1 anlaşılmaktadır. Osmanlı Türkçesi sözlüklerinde aytış- ve ayduş- / eydiş- / eydüş- gibi varyantları tespit edilememiştir.

\section{ATIŞ- VE AYTIŞ- SÖZCÜKLERININ ÇAĞDAŞ LEHÇELERDE VE TÜRKİYE TÜRKÇESINDE KULLANIMI}

Türkiye Türkçesinde standart dilde aytış- eylemi kullanılmamaktadır. Batı Türkçesinde genellikle eyit- şekliyle kullanılan eylem; bugün Türkiye Türkçesi ağızlarında aydış- / aydeş- / eydiş- / idiş- varyantlarıyla "tartışmada aksi cevap vermek, 
inatlaşmak; tartışma yapmak, dil kavgası etmek; kötülemek, uğraşmak; itişmek, didişmek" anlamları ile kaydedilmiştir (Derleme Sözlügü I, 1993, s. 412). Ağızlarda ayrıca eytiş "hal, hatır sorma" (Derleme Sözlüğü V, 1993, s. 1827) sözcüğü de tespit edilmiştir. Genellikle sedalı, öndamaksıllaşmış, daralmış varyantları ile ortaya çıkan eylemin dönüşlü şeklinin de Derleme Sözlüğü'nde aydın"sövmek, kötü kötü söylenmek; darılmak; kendi kendine söylenmek; şikayet etmek" anlamıyla mevcut olduğu dikkati çeker kaydedilmiştir (Derleme Sözlüğü I, 1993, s. 412). Aydlş̧-/aydeş-/eydiş-/idiş- eylemleri "tartışmak, ağız kavgası yapmak" anlamlarıyla karşılıklı olarak konuşmanın sohbet değil, tartışma şeklini ifade etmek amaciyla kullanılmıştır. Kamus-1 Türki'de yer almayan sözcük Türkiye Türkçesi ağızlarında görülmektedir. Bu tür örnekler Türkiye Türkçesi ağızlarında tanıklanır; tap- "bulmak" anlamıyla Türkçe Sözlük’te yer almazken Derleme Sözlüğünden yerel ağızlarda yaşadığı tespit edilir.

Atış ve aytış- eylemlerinin çağdaş Türk lehçelerindeki anlam alanlarına bakıldığında Kırgız Türkçesinde atış- "hep beraber ateş etmek; atış yarışı yapmak; karşılıklı atışmak"; atış "ateş etme, atma"; atışuu "hep beraber ateş etme; atış müsabakası yapma; karşılıklı atışma"; aytış- "dayatışmak, çekişmek; kavga etmek; münazaa etmek; bahse girişmek"; aytış "söyleyiş̧; takılma; münakaşa; münazaa; ilmi müzakere; bahse girişme" anlamları ile yer aldığı görülür (Yudahin ve Taymas, 1998, s. 59, 72). Buradaki aytış- eyleminin anlamı Türkiye Türkçesi ağızlarındaki anlam ile benzerlik göstermektedir. Hakas Türkçesinde aydls-, aytıs- "konuşmak, söyleşmek; sözleşmek"; aydls "konuşma, söyleşme"; atıs- "birlikte atmak; birlikte ateş etmek; atışta yarışmak; birbirine atmak"; atıs "atış, atma; kurşuna dizme" şeklinde anlamlandırılır (Naskali, 2007, s. 55, 59, 60). Kazak Türkçesinde aytıs "iki adam arasında veya iki grup arasında karşılıklı söylenen ağıt, şiir; siyasi ilmi meselelerle ilgili tartışma"; aytısuv "bir grup ile ikinci grup veya iki şahıs arasında karşılıklı fikir bildirme; münakaşa etmek"; atıs "savaş"; atısuv "savaşmak; birbirine düşman olmak" (Oraltay, 1984, s. 9, 23) şeklindedir. Kazak Türkçesinde türe aytış "kısa kısa şiirle yapılan atışma"; süre aytıs "tecrübeli aşıların uzun atışması"; qızıl kenirdek aytıs "dava, kavga, çatışma" kullanımları da mevcuttur. Özbek Türkçesinde de åtış "atmak; savaşçı silahlardan ok koparma, oku hedefe vurma egzersizi; savaştaki iki tarafin birbirine karşı sürekli ok koparması, ok atması, ok yağdırması, atma", åtış- "eldeki şeyi uzağa veya hedefe firlatmak, atmak, atıp yollamak, yollayıp atmak, terk etmek, düzenlemek, bir silah vasitasıyla ok, taş, mayın vb. ayırmak, atmak, silah vasitasıyla vurup zarar vermek veya öldürmek, koymak, atmak, uçmak, kaymak" (Şenel, 2020, s. 111); äytış- "fikrini, amacını sözlü bir şekilde açıklamak, anlamlandırmak, söylemek, demek, teklif etmek, çağırmak; sözle atışmak, tartışmak" (Şenel, 
2020, s. 188) ve "arası açılmak; bozuşmak; ağız kavgası yapmak; çekişmek" anlamlarıyla kaydedilir. Tespite göre Kıpçak ve Karluk grubu Türk lehçelerinde atış- "karşılıklı atmak, ateş etmek, atış yarışı yapmak, savaşmak"; aytış- eylemi "söyleşmek, çekişmek, kavga etmek" anlamlarıyla kullanılmaktadır.

Kökünün aytış- mı atış- olduğu açık olmayan atışma "saz şairleri karşılıklı deyiş söyleme" sözcügünün Oğuz grubundan Azerbaycan Türkçesinde deyişme ile karşılandığı görülür. Azerbaycan Türkçesinde deyişme "mübahise, sözleşme, söyüşme, höcetleşme, dalaşma; aşıklar arasında yarış ve müsabike mahiyyetinde olan şeirleşme"; deyişmek "birbiri ile mübahise etmek, birbiri ile sözleşmek, höcetleşmek, söyüşmek; şeirle yarışmak; deyiş "söz döyüştürme" (ADİL I, 2006, s. 565) şeklinde verilir. Aynı sözlükte atışma "iki tarafın ya da iki adamın karşı karşıya durup birbirine gülle atması, ateş açması; sözleşme, birbirine ağır sözler deme, söyüşme, dava-dalaş" (ADİL I, 2006, s. 161) açıklaması ile verilir. Atış- "sözle tartışma" anlamı burada da görülür.

16. yüzyıldan itibaren halk hikâyelerinde, atışma özelliği taşıyan karşılıklı şiir söyleme örneklerinin görüldüğü araştırmacılar tarafından kaydedilir (Artun, 2013, s. 74). Fakat bu gelenek sadece bir terimle karşılanmaz. Âşıklık geleneğinde en az iki aşı̆̆ın saz ve sözle birbirlerine karşı sitemli deyişmelerinin karşılama, deyişme, atışma, karşıberi, müşaare, bağlama, tekellüm gibi terimlerle adlandırıldığı belirtilir (Artun, 2013, s. 73). Türkiye'de atışma, Azerbaycan'da deyişme, Kıpçak ve Karluk lehçelerinde aytıs adlarıyla anılan bu kavram, Türk kültürünün eski bir geleneği olduğu hâlde, sözlü dilin unsuru olduğundan yazılı dilde izini sürmek zor olmaktadır. Türkçenin tarihî devirlerine ait sözlüklerde de müşaare, tekellüm gibi adlarla yer almıştır. Lügat-i Nâcî'de (19. yüzyıl) Arapça müşāare "İki şair birbirine şiir söylemek, şiir söyleşmek" açıklaması bunu örneklendirmektedir (Kartal, 2009, s. 495).

1942 yılında yayımlanan Anayasa - Gerekçeler, Taslak, Sözlük adlı eserde dilimizde ayıtmak, eyitmek sözlerinin ortaklık kipi "aytışma"nın münakaşa karş1lığı olduğu; bunun halk ağzında atışma şeklini aldığı; münakaşa için "aytışma" teriminin uygun görüldüğü belirtilir (TDK, 1942, s. 34). Bu maddede iki kelime ve bir de sayllan engellerin sırası üzerinde aytışmalar yapılmıştır (TDK, 1942, s. 22) cümlesi de kayıtlara geçmiştir. Buradaki değerlendirme ise farklı bir çalışmanın malzemesidir.

Cumhuriyet döneminde dili sadeleştirmek için geniş çaplı bir çalışma başlatılmıştır. 1933 yılında Türk Dili Tetkik Cemiyeti tarafından halk ağzından söz derleme çalışmaları başlamış; dil anketi 
düzenlenmiş, gazetelerde yer alan dil köşelerinde önerilen yeni kelimelere yer verilmiştir. Türk Dili Tetkik Cemiyeti halk ağzından derlenen ve tarama ile elde edilen sözcükleri 1934 yılında Osmanlıcadan Türkçeye Söz Karşılıkları Tarama Dergisi adı ile yayımlamıştır. Osmanlıcadan Türkçeye Söz Karşılıkları Tarama Dergisi'nde "muaraza etmek", "mücadele etmek", "münazaa etmek" birleşik eylemleri için atışmak karşılığı verildiği görülür (TDTC, 1934, s. 536, 567, 581). Osmanlıca kelimelere Türkçe karşllıklar bulma çalışmaları içerisinde yayımlanan Türkçeden Osmanlıcaya Cep Kılavuzu'nda "münakaşa etmek", "mübahase etmek" birleşik eylemlerine karşılık aytışmak, aydışmak, çekişmek, deyişmek eylemi önerilir (TDK, 1935, s. 33). Osmanlıcadan Türkçeye Söz Karşılıkları Tarama Dergisi'nde "mükâleme etmek" için önerilenler "ayıtmak, eydişmek, eytişmek, konuşmak, söyleşmek" sözcükleridir (TDTC, 1934, s. 575). Bu çalışmalarda Osmanlıca bir kelimenin Anadolu ağızlarındaki karşılığının yanında çeşitli lehçelerdeki karşılıkları da kullanılmıştır. TDK Türkçe Sözlük'ün 1945 baskısında, kılavuzlarda Osmanlıca sözcüklere önerilen Türkçe karşılıklar arasında yer alan adanç "vaat"; açın "keşif"; bayar "yüce"; bilit "ilan" gibi pek çok sözcük vardır. Bu sözcükler daha sonraki baskılarda çıkarılmıştır. Bu durum aytış- sözcüğünün de bu yolla Türkçe Sözlük'e girmiş olduğunu düşündürmektedir. Daha sonraki basımlarda anlam ilgisi dolayısıyla sözlükten çıkarılmamış olmalıdır.

Eski Anadolu Türkçesi metinlerinde görülen aytt- / eyitsözcüklerinin bugün ölçünlü dilde mevcut olmadığı hâlde ağızlarda yaşıyor olması tabii bir durumdur. Nitekim Eski Anadolu Türkçesi dönemi eserlerinde tespit edilen bıldır, yiygi, bayımak gibi sözcükler yerel ağızlarda mevcuttur. Ağızlarda yaşayan aydış- / eydiş- / aydeşgibi şekillerin bu şekilde korunmuş olması mümkündür.

Türkiye Türkçesinde ağızları ağırlıklı olarak ses, yapı ve sözvarlığı bakımından Oğuzca özelikler barındırır. Bununla birlikte ağızlarda Oğuzca dişı unsurlar da yaşamaktadır. XIII. yüzyılda itibaren Anadolu'ya göç eden Oğuzlar kendi yazı dillerini meydana getirmeye başlar. Selçuklu ve Osmanlı coğrafyasına göçlerle Kıpçak ve Karluklar da geldiğinden, oluşmaya başlayan bu yazı dilinde Kıpçak ve Karluk dil özelliklerinin yer aldığı bilinir. Türkiye Türkçesi ağızlarında yer alan Kıpçak ses ve yapı özelliklerinin yanı sıra sözvarlığındaki bazı kelimelerin de bu yolla günümüze ulaştığı düşünülebilir. 


\section{SONUÇ}

11. yüzyıldan itibaren tanıklanan atış- "herhangi bir şeyi atmak" eylemi, daha Karahanlı Türkçesi döneminde anlam alanını genişleterek "suç atışmak" anlamıyla kullanılır. Eski Anadolu Türkçesinde Dede Korkut'ta "söz atışmak" anlamıyla yer alır. Osmanlı Türkçesi sözlüklerinde ok atış-, sözle atış-, kura atışkullanımları tespit edilir. Eylemin Türkiye Türkçesinde "karşılıklı nesne atışmak" anlamının kullanımdan düştügü; "söz atışmak, tartışmak" anlamı ile varlığını korumuş olduğu görülür.

11. yüzylldan itibaren aytış- "barışmak, birbirlerine sormak, birbirlerinin hâl ve hatırlarını sormak, söyleşmek" anlamları ile tanıklanır. Eski Anadolu Türkçesi metinlerinde sık kullanılmadığı, tespit edilen örneklerde de "karşıllıkı konuşmak" anlamını muhafaza ettiği görülür. Osmanlı Türkçesi metinlerinde aytış- ve varyantları tespit edilemez; Meninski lügati, Lehçe-i Osmani, Kamus-ı Türki gibi sözlüklerde yer almaz. Aydış- ve varyantları, Eski Anadolu Türkçesi metinlerinde tespit edilen, bugün standart dilde yer almayan ama yerel ağızlarda korunan bazı kelimeler gibi sınırlı kullanım alanında varlığını korumuştur. "Halk şairlerinin belli bir ayak çerçevesinde karşılıklı atışması” karşılığındaki atışma sözcügünün aytışeyleminden türemiş olması hem Osmanlı Türkçesi dönemi sözlüklerinde yer almaması hem de 14. yüzyıldan itibaren eylemin öndamaksıllaşmış şeklinin daha sık kullanılması sebebiyle daha zayıf bir ihtimal olarak görünmektedir. Ayt- kökünden türediği düşünülen atışma sözcüğünün eydişme / edişme formunda gelişim göstermemesi bu görüşü desteklemektedir. Ancak sözcügün atışma < aytışma şeklinde bir değişim göstermesi de mümkün olduğu için güncelleme yoluyla atışma formunu almış olması da değerlendirilmelidir.

Dilin söz varlığında kullanım sıklığını kaybeden ve bellek sözlüğünden silinen Türkçe sözcükler, ödünçlemeler gibi çözümlenemez olunca sık kullanılan, ses, anlam ve yapı bakımından benzer olan ve anlamı daha yaygın bilinen saydam sözcüklerle değişime girer (Akalın, 2017, s. 20). tạa batmak daya batmak "şaşakalmak, hayrete düşmek" kalıp sözünün zamanla geçirimsizleşmesi sonucunda ses ve anlam bakımından benzerlik gösteren farklı yapıdaki dona kalmak deyimine değişmesi ve Osmanlıda yazışmalardan sorumlu kişinin unvanı olan bitikçi sözcüğünün 16. yüzyıldan sonra beylikçi olarak kullanıldığının tespit edilmesi bu kelimelerin konuşanlar tarafından artık tanınmıyor olmasından kaynaklı güncellemenin birer örnekleridir (Akalın, 2017, s. 21-22). Sözcük türetme yollarından biri olarak değerlendirilen güncellemede, kullanılmayan, anlamı unutulan dolayısıyla 
çözümlenemeyen geçirimsiz (opaque) sözcükler ses ve anlam bakımından en uygun sözcükle karşılandığı için aytışma sözcüğünün atışma şeklinde güncellenmiş olması kuvvetli bir ihtimaldir.

\section{KISALTMALAR}

ADİL : Azərbaycan Dilinin İzahlı Lüğəti

TDK : Türk Dil Kurumu

TDTC : Türk Dili Tetkik Cemiyeti

\section{KAYNAKÇA}

Akalın, Ş. H. (2017). Türkçede söz oluşum yollarından biri: güncelleme. Akademik Ağamusa Axundovun 85 illiyinə həsr olunmuş "Ăgamusa Axundov vo Azorbaycan Filologiyası" Beynalxalq Elmi Konfransin Materiallart. Bakı.

Artun, E. (2013). Çukurova aşıklık geleneğinde atışma. Folklor / Edebiyat. 19(75), 73-116.

Ayan, H. (1979). Hurşî̀-nâme (Hurşî̀d ü Ferahşâd) inceleme-metinsözlük-konu dizini. Erzurum: Atatürk Üniversitesi Basımevi.

Azərbaycan Dilinin İzahlı Lüğati (Ağamusa Axundov, C., Red.) (2006). Bakü.

Cin, A. (2004). Ali Klssa-i Yûsuf (H.630/M.1233) (inceleme-metindizin). Yayımlanmamış doktora tezi, Ankara Üniversitesi, Ankara.

Eckman, J. (1995). Nehcü'l-ferādīs uştmahlarnı̀ açuk yolı cennetlerin açı yolu $ı$ metin II tıpkibasım. Ankara: Türk Dil Kurumu Yayınları.

Ercilasun, A. B. ve Akkoyunlu, Z. (2015). Kâşgarlı Mahmud dîvânu lugâti't-Türk giriş-metin-çeviri-notlar-dizin. Ankara: Türk Dil Kurumu Yayınları.

Ergene, O. (2017). Sibicabi gülistan tercümesi giriş-dil incelemesimetin-çeviri-dizinler-tıpkıbaskı. Ankara: Türk Dil Kurumu Yayınlar1.

http://lugatim.com/s/at\%C4\%B1\%C5\%9Fmak (Erişim tarihi: 14.02.2021)

http://lugatim.com/s/ayt\%C4\%B1\%C5\%9Fmak (Erişim tarihi: 14.02.2021) 
İnce, A. (2015). Nimetu'llâh Ahmed lügat-i nimetu'llâh. Ankara: Türk Dil Kurumu Yayınları.

Karabey, T., Şığva, B. ve Babür, Y. (2015). Hâce-i cihân ve netîce-i cân inceleme - tenkitli metin. Ankara: Akçağ Yayınları.

Karaörs, M. M. (2006). Ali Şir Nevayi, nevādirü'ş-şebāb. Ankara: Türk Dil Kurumu Yayınları.

Kartal, A. (2000). Lügat-i Nâcî Muallim Naci. Ankara: Türk Dil Kurumu Yayınları.

Kırkkılıç, A. ve Sancak, Y. (2017). Ahterî Mustafa Muslihuddin elKarahisarî ahteri-yi kebir. Ankara: Türk Dil Kurumu Yayınları.

Kök, A. (2004). Karahanlı Türkçesi satır-arası Kur'an tercümesi (TIEM $1 v$-235v/2) (giriş-metin-inceleme-dizin). Yayımlanmamış doktora tezi, Hacettepe Üniversitesi, Ankara.

Naskali, E. G., Butanayev, V., İsina, A., Şahin, E., Şahin, L. ve Koç, A. (2007). Hakasça Türkçe sözlük. Ankara: Türk Dil Kurumu Yayınlar1.

Oraltay, H., Yüce, N. ve Pınar, S. (1984). Kazak Türkçesi sözlüğü. İstanbul: Türk Dünyası Araştırmaları Yayını.

Özçelik, S. (2016). Dede Korkut -Dresden nüshast-, giriş, notlar. Ankara: Türk Dil Kurumu Yayınları.

Stachowski, M (2019). Kurzgefasstes etymologisches worterbuch der Turkischen sprache. Krakow: Ksiegarnia Akademicka.

Şemseddin Sami (1317). Kâmûs-i Türkî. İstanbul: İkdam matbaası.

Şenel, Ö. (2020). Dîvânu Lugâti’t-Türk ile Özbek Türkçesinin karşılaştırmalı söz varlığı üzerine inceleme. Yayımlanmamış yüksek lisans tezi, Artvin Çoruh Üniversitesi, Artvin.

Tietze, A. (2009). Tarihi ve Etimolojik Türkiye Türkçesi lugatı sprachgeschichtliches und etymologisches wörterbuch des Türkei-Türkischen. Osterreichischen Akademie der Wissenschaften, Wien.

Toparlı, R., Eyövge, Y. B. ve Yılmaz, Y. (2016). Müntahabât-ı lügât-i Osmâniyye. Ankara: Türk Dil Kurumu Yayınları.

Türk Dil Kurumu (1935). Türkçeden Osmanlıcaya cep kılavuzu. Ankara: Türk Dil Kurumu Yayınları. 
Türk Dil Kurumu (1942). Anayasa - gerekçeler, taslak, sözlük. Ankara: Türk Dil Kurumu Yayınları.

Türk Dil Kurumu (1957). Türkiyede halk ă̆zından söz derleme dergisi. Ankara: Maarif Matbaası.

Türk Dil Kurumu (1993). Türkiye'de halk ağzından söz derleme sözlügüu. Ankara: Türk Dil Kurumu Yayınları.

Türk Dil Kurumu (1996). XIII. yüzyıldan beri Türkiye Türkçesiyle yazılmış kitaplardan toplanan tanıklarlyla tarama sözlü̆̆̈̈ III, Ankara: Türk Dil Kurumu Yayınları.

Türk Dili Tetkik Cemiyeti (1934). Osmanlıcadan Türkçeye Söz karşılıkları tarama dergisi 1. Ankara: Türk Dil Kurumu Yayınlar1.

Wilkens, J. (2021). Handwörterbuch des Altuigurischen AltuigurischDeutsch-Türkisch Eski Uygurcanin el sözlüğ̈̈ Eski UygurcaAlmanca-Türkçe. Akademie der Wissenschaften zu Göttingen.

Yıldız, M. (2018). Kutb’un Farsçadan Türkçeye çevirdiği hüsrev ü şîrîn adlı mesnevisinde fiiler. Yayımlanmamış yüksek lisans tezi, Selçuk Üniversitesi, Konya.

Yüce, N. (1988). Mukaddimetü'l-Edeb Hvārizm Türkçesi ile tercümeli Şuşter nüshası giriş, dil özellikleri, metin, indeks. Ankara: Türk Dil Kurumu Yayınları. 